\title{
Streptomyces spp. A POTENTIAL BIOCONTROL AGENT AGAINST Ganoderma boninense OF BASAL STEM ROT
}

\author{
PEI HUI LIM*; JUALANG AZLAN GANSAU* and KHIM PHIN CHONG**
}

\begin{abstract}
Oil palm industry in Malaysia is suffering from one major disease known as basal stem rot (BSR), caused by Ganoderma species. Microbes were isolated from soil samples collected from Crocker Range of Sabah and the percentage inhibition of radial growth (PIRG) against Ganoderma boninense was determined. There were 72 types of actinomycetes isolated from 20 soil samples and the most potential actinomycete (A19) showed the highest PIRG with $80.00 \%$. The interaction of A19 with G. boninense was observed using scanning electron microscopy (SEM). G. boninense was inhibited by anti-fungal effect of A19 due to hyphae damage and A19 was successfully identified as Streptomyces spp. Metabolites of Streptomyces spp. A19, were extracted and ethyl acetate extract showed the highest inhibition to G. boninense. Minimum inhibitory concentration (MIC) of Streptomyces spp. A19 ethyl acetate extract was $0.18 \mathrm{mg} \mathrm{ml}^{-1}$. The extracts were then fractionated through solid phase extraction (SPE). SPE fractions (0.02 $\left.\mathrm{mg} \mathrm{ml}^{-1}\right)$ showed better inhibition to $\mathrm{G}$. boninense compared to crude extracts with the same concentration. Several antimicrobial compounds (ribostamycin, benzylmalic acid, landomycin B and salinomycin) were detected in these samples using Liquid chromatography-mass spectrometry (LC-MS). These metabolites may contribute to the antagonistic effect against $\mathrm{G}$. boninense.
\end{abstract}

Keywords: basal stem rot, biology control, G. boninense, oil palm, Streptomyces spp.

Date received: 13 September 2017; Sent for revision: 13 October 2017; Received in final form: 2 January 2018; Accepted: 2 February 2018.

\section{INTRODUCTION}

Oil palm is the golden crop of Malaysia because it contributes to profitable income for the country and help to reduce poverty in Malaysia. The export from palm oil or palm oil products contributes approximately RM 64.58 billion to Malaysia's revenue in 2016 with the planted area of 5.74 million hectares (MPOB, 2017). However, the oil palm industry in South-east Asia is suffering from one major disease, the basal stem rot (BSR) caused by

\footnotetext{
* Biotechnology Programme, Faculty of Science and Natural Resources, Universiti Malaysia Sabah, Jalan UMS, 88400 Kota Kinabalu, Sabah, Malaysia.

** FGV Chair on Sustainable Oil Palm Management, Faculty of Sustainable Agriculture, Universiti Malaysia Sabah, Locked Bag No. 3, 90509 Sandakan, Sabah, Malaysia. E-mail: chongkp@ums.edu.my
}

Ganoderma species. Ganoderma is a white rot fungus and the term 'white rot' derives from the fungus ability to degrade specifically the lignin component of wood while leaving the white cellulose exposed. Many methods have been attempted to control BSR, but to date, no method gives good control of Ganoderma infection in established plantations (Chong et al., 2011). Cultural practice such as soil mounding is not effective in controlling BSR and it only helps to prolong the economic life of the yielding palms affected by BSR. Chemical control such as trunk injection of systemic fungicides has also been reported (Chung, 1990; George et al., 1996) and at most, some systemic fungicides managed to prolong the economic life of BSR infected palms, but they failed to give effective control of the disease because treated BSR infected palms will eventually collapse. The difficulties in controlling BSR may be due to the 
failure of planters to recognise the infected palms at the early stage and in addition to this, Ganoderma also has several resting stages such as pseudosclerotia (melanised mycelium) and basidiospores (Susanto et al., 2005) that are more resistant to fungicides. The use of biological control agents such as Trichoderma spp (Soepena et al., 2000; Alexander and Chong, 2014), Bacillus spp. (Alexander and Chong, 2014), Agrobacterium radiobacter, Burkholderia cepacia and Pseudomonas syringae (Maizatul and Idris, 2009) has been reported and showed varied results. The Streptomyces genus in actinomycetes group showed a high inhibition percentage against $G$. boninense in vitro through antibiosis and the lysis of hyphae resulting in abnormal hyphae growth (Tan et al., 2002). The Streptomyces spp. was proven to inhibit the growth of G. boninense in vitro (Shariffah et al., 2011). However, not many reports on actinomycetes against Ganoderma were documented. In this study, the potential of actinomycetes from the rich biodiversity of Crocker Range in Sabah was studied. Actinomycete with the highest percentage inhibition of radial growth (PIRG) to $G$. boninense was identified and the potential bioactive compounds were extracted and identified.

\section{MATERIALS AND METHODS}

\section{Soil Sampling and Isolation of Potential Antagonists from Soil Samples}

Twenty soil samples were collected randomly from Crocker Range forests area $\left(5.4008^{\circ} \mathrm{N}, 116.1033^{\circ}\right.$ E). Soil samples were collected $15 \mathrm{~cm}$ in depth from the ground using sterilised pvc pipes $(5 \times 15 \mathrm{~cm})$. Soil samples were packed in ziplock bags and stored in a container with icepacks during transportation from sampling site to laboratory.

The isolation of microbes of interest was conducted using dilution plate method. A serial dilution of the soil suspension from $10^{-1}$ to $10^{-8}$ was prepared. To prepare a soil suspension with $10^{-1}$ dilution, $10 \mathrm{~g}$ of soil was suspended into $90 \mathrm{ml}$ of sterile distilled water in a $250 \mathrm{ml}$ conical flask. The suspension was then serially diluted to $10^{8}$. An aliquot of $100 \mu \mathrm{l}$ of each dilution was taken and spread evenly on the surface of actinomycete isolation agar (AIA) (Difco ${ }^{\circledR}$ ) using a L-shaped glass spreader. All plates were incubated at room temperature for one to two weeks. Colonies formed on the AIA plates were then sub-cultured on oatmeal agar (OA) to obtain a pure culture.

\section{Dual Culture Assay}

The assays were conducted using potato dextrose agar (PDA). G. boninense mycelial plug $(8 \mathrm{~mm})$ was taken from $G$. boninense pure culture stock of 10 days old which was previously identified by Chong et al. (2011) and placed $30 \mathrm{~mm}$ from one side of the PDA plate. After two days, a loopful of the potential antagonist actinomycetes was streaked $30 \mathrm{~mm}$ from the G. boninense plug. The radial growth of the pathogen in the dual culture was measured after seven days of incubation at room temperature $\left(28 \pm 1^{\circ} \mathrm{C}\right)$ and the PIRG was calculated as described by Bivi et al. (2010). The formula for PIRG is as follows: [(R1-R2)/R1] x 100\% where, $\mathrm{R} 1$ is the radial growth of $G$. boninense in the control plate while $\mathrm{R} 2$ is the radius of the $G$. boninense colony in the direction towards the antagonist colony. Plates with only G. boninense, served as controls. Each assay was repeated thrice. Antagonist with the highest PIRG against $G$. boninense was identified and further studied.

\section{Scanning Electron Microscopy (SEM) Study of the Interaction}

The interaction of isolate with the highest PIRG against the pathogen was observed using Zeiss $\mathrm{EVO}^{\circledR} 10 \mathrm{MA}$ SEM. The zone of interaction between $G$. boninense and the isolate in dual culture assay (Day 7) was prepared for observation. G. boninense fungal mycelia in the middle of the agar plate were cut to approximately $1.0 \times 1.0 \mathrm{~cm}$ in size using scalpel. The samples were then air dried in laminar flow at room temperature for about 3 to $4 \mathrm{hr}$. The samples were mounted onto aluminium stubs using conductive double sided adhesive carbon tabs (Nisshin EM. Co. Ltd). The stubs were then sputter coated with gold-palladium (Emitech K550x carbon coater) from different angles to ensure a complete and uniform film over sample surfaces. Coated surfaces of samples were viewed at $15 \mathrm{kV}$ voltage.

\section{Identification of Microbes}

Actinomycete (A19) with the highest PIRG was identified using molecular technique. The method in extracting the DNA and PCR work as described by Latifah et al. (2002) with some modifications. Primers used were Eub 518: 5' - ATT ACC GCG GCT GCT GG -3' and Eub 338: 5' - ACT CCT ACG GGA GGC AGC AG -3'. Forward and reverse sequences were assembled in BIOEDIT v.7.2.5.0 and used for BLASTN with NCBI GenBank database (http:// www.ncbi.nlm.nih.gov). Sequences found in the database with the highest nucleotide similarities ( $97 \%$ or more) were considered as the closest relative of the query sequence.

\section{Anti-microbial Assay of Crude Extracts}

Actinomycete with the highest PIRG (A19) was cultured in mannitol peptone broth for five days. The broth culture was then extracted using hexane, ethyl 
acetate and acetone respectively. The solvent phase was collected and dried using rotary evaporator $\left(\right.$ Stuart ${ }^{\circledR}$ ) at $37^{\circ} \mathrm{C}$ for anti-microbial assay (Lakshmi and Selvi, 2013). Agar dilution method (0.20 to $1.0 \mathrm{mg} \mathrm{ml}^{-1}$ ) was used to test the anti-microbial efficacy of the extracts (dissolved in 1\% Dimethyl sulfoxide, DMSO) on G. boninense (Chaudhary et al., 2013). All assays were conducted in triplicates, and mean values and standard deviations of $G$. boninense growth diameter were calculated. Mean significance of $G$. boninense diameter for different treatments with different concentrations was subjected to Univariate Analysis of variance (two-way ANOVA) with means compared using Tukey's Range Test. Differences between the mean values were considered significant when $p<0.05$.

\section{Determination of Minimum Inhibitory Concentration (MIC)}

MIC A19 extracts were determined by testing the concentration of the extracts from 0.02 to $0.18 \mathrm{mg}$ $\mathrm{ml}^{-1}$. The stock solutions and agar preparation were carried out as in section 2.5 but with different volume of stock solutions used. Seven days old G. boninense mycelial plug was placed in the centre of each petri plate. Diameter of $G$. boninense was measured from day one to day seven for determination of the minimum concentration which caused inhibition to G. boninense.

\section{Solid Phase Extraction (SPE)}

Two types of cartridges, Phenomenex Strata SI-1 $(55 \mu \mathrm{m}, 70 \AA$ Å) silica-based sorbent $500 \mathrm{mg} 6$ $\mathrm{ml}^{-1}$ (normal phase) and Phenomenex Strata C18-E $(55 \mu \mathrm{m}, 70 \AA)$ silica-based sorbent $500 \mathrm{mg} 6 \mathrm{ml}^{-1}$ (reversed phase) were used. Crude extract samples preparation of the selected isolate was prepared as in section 2.6. For Strata C18-E cartridges, methanol $(4 \mathrm{ml})$ was used for conditioning and activating the sorbent bed of the cartridge. Cartridges were later equilibrated with $2 \mathrm{ml}$ Milli-Q water to prepare the sorbent for optimised interaction with the analyte. Samples (5 ml) with the concentration of $50 \mathrm{mg} \mathrm{ml}^{-1}$ were then loaded into the cartridges, which were washed with $5 \mathrm{ml}$ of $20 \%(\mathrm{v} / \mathrm{v})$ acetonitrile to remove any impurities from samples, and finally eluted with $5 \mathrm{ml}$ of ethyl acetate. For Strata SI-1 cartridges, methanol (4 ml) was used for conditioning. Cartridges were later equilibrated with $2 \mathrm{ml}$ hexane. Samples $(5 \mathrm{ml})$ with the concentration of $50 \mathrm{mg} \mathrm{ml}^{-1}$ were then loaded into the cartridges, which were washed with $5 \mathrm{ml}$ of $2 \%(\mathrm{v} / \mathrm{v})$ acetone and finally eluted with $5 \mathrm{ml}$ of $50: 50 \%(\mathrm{v} / \mathrm{v})$; hexane: ethyl acetate. A19 C18 elute fraction [A19 C18(E)], A19 C18 wash fraction [A19 C18(W)], A19 Si-1 elute fraction [A19 Si-1(E)], and A19 Si-1 wash fraction [A19 Si-1(W)] were collected and dried using rotary evaporator $\left(\right.$ Stuart $\left.^{\circledR}\right)$ at $37^{\circ} \mathrm{C}$. The final concentration was adjusted to $0.02 \mathrm{mg} \mathrm{ml}^{-1}$. Agar dilution method was used to test the anti-microbial efficacy of the extracts on G. boninense. The concentration tested in the anti-microbial activity assay was $0.02 \mathrm{mg}$ $\mathrm{ml}^{-1}$. Seven days old $G$. boninense mycelial plug was placed in the centre of each petri plate. Diameter of G. boninense was measured at Day 7. G. boninense growth inhibition percentage was calculated.

\section{Liquid Chromatography Mass Spectrometry (LC-MS) Compounds Identification}

Identity of potential bioactive compounds from A19 C18(E) and A19 Si-1(W) were identified using LC-MS. The LC-MS analysis was carried out using an acquity Waters ultra-performance liquid chromatography (UPLC) coupled with synapt high definition mass spectrometer quadrupoleorthogonal acceleration, time-of-flight detector equipped with an electrospray ionisation (ESI) source. The mobile phase used was Acetonitrile: Water + Trifluoroacetic acid 0.1\%; 80:20. The identification of the individual compounds were done using METLIN metabolites database (https: / / metlin.scripps.edu/) on the basis of the mass fragments and $\mathrm{m} / \mathrm{z}$ values of each component.

\section{RESULTS}

\section{PIRG of the Potential Antagonists against G. boninense}

Out of the total of 195 isolates from the 20 soil samples with different morphology, there were only 72 actinomycete isolates. However, only 14 actinomycete isolates showed PIRG greater than $50 \%$ against the tested pathogen (Table 1). Actinomycete isolate with the highest PIRG $(80 \%)$ was given an identity code as A19. The dual culture assay of A19 to $G$. boninense is illustrated in Figure 1.

\section{Observation on Morphological Changes of G. boninense during the Interaction with A19}

Interaction zone of antagonist (A19) and G. boninense in dual culture assays were examined under SEM. Figure $2 a$ is the control G. boninense with dense fungal mat. Figure $2 b$ shows $G$. boninense hyphae with the presence of A19. The density of the fungal mat was much lower compared to control $G$. boninense and distorted hyphae were also observed.

\section{Identification of A19}

The gel electrophoresis images from crude DNA of A19 is shown in Figure 3a. The gel electrophoresis 


\begin{tabular}{ccc}
$\begin{array}{c}\text { TABLE 1. ACTINOMYCETES ISOLATES SHOWING MEAN } \\
\text { PIRG GREATER THAN 50\% }\end{array}$ \\
\hline No. & $\begin{array}{c}\text { Actinomycetes } \\
\text { isolate }\end{array}$ & $\begin{array}{c}\text { Mean } \\
\text { PIRG (\%) }\end{array}$ \\
\hline 1 & A19 & 80.00 \\
2 & A16 & 78.18 \\
3 & A72 & 70.30 \\
4 & A14 & 69.70 \\
5 & A42 & 67.27 \\
6 & A3 & 66.06 \\
7 & A48 & 65.45 \\
8 & A46 & 63.03 \\
9 & A59 & 61.82 \\
10 & A20 & 60.00 \\
11 & A44 & 55.15 \\
12 & A56 & 54.55 \\
13 & A34 & 53.94 \\
14 & A43 & 50.30 \\
\hline
\end{tabular}

Note: 'A' denotes actinomycetes isolates.

PIRG - percentage inhibition of radial growth. images from PCR amplification of A19 using EUB 338 and EUB 518 primer are shown in Figure $3 b$. The A19 amplicon was about 200 bp. Figure 4 shows the assembled sequences of A19 that was used for the BLASTN in NCBI GenBank database (http:// www.ncbi.nlm.nih.gov). Sequences found in the database with the highest nucleotide similarities were considered as the closest relative of the query sequence. The identity of A19 was confirmed using molecular technique as Streptomyces spp. (Table 2).

\section{Anti-microbial Activity of Crude Extracts of Streptomyces spp. A19 against G. boninense}

Ethyl acetate extract of Streptomyces spp. A19 showed the highest inhibition against $G$. boninense and was significantly higher $(p<0.05)$ compared to other extracts. Figure 5 shows the comparison of G. boninense growth inhibition percentage at different concentrations of Streptomyces spp. A19 solvent extracts. Ethyl acetate extract $\left(1 \mathrm{mg} \mathrm{ml}^{-1}\right)$ of Streptomyces spp. A19 gave $90.59 \%$ of inhibition to
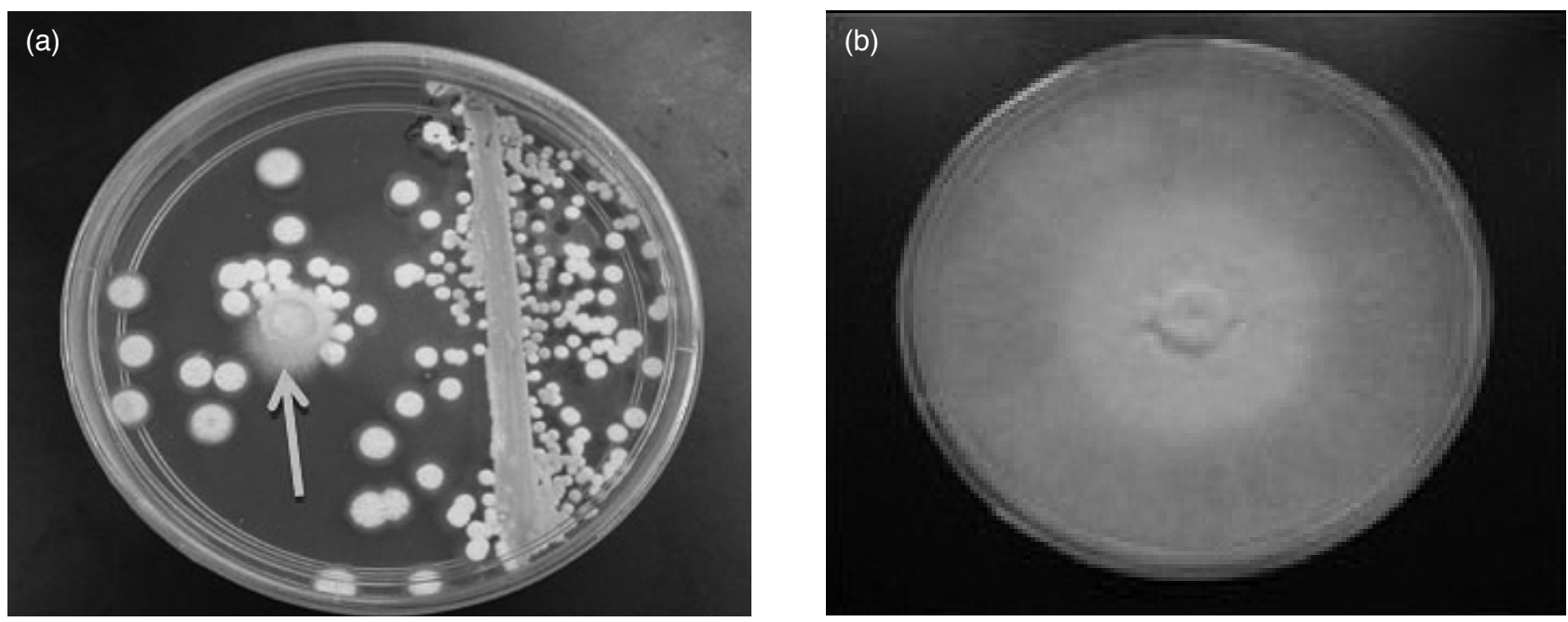

Figure 1. Morphology of potential biological control agent (A19) and G. boninense, a. Actinomycete isolate (A19) and G. boninense (arrowed) with highest percentage inhibition of radius growth $(80 \%)$; $b$. Control plate of $\mathrm{G}$. boninense.


Figure 2. Micrograph of G. boninense under scanning electron microscopy observation, a. Morphology of G. boninense hyphae without interaction with the antagonist (control) at 2000X magnification; $b$. Morphology of $\mathrm{G}$. boninense hyphae interaction with A19 at 2000X magnification. Note: Low fungal mat density and distorted hyphae were observed for G. boninense with A19. Circles showed the morphology differences between control G. boninense and G. boninense with A19. 
(a)

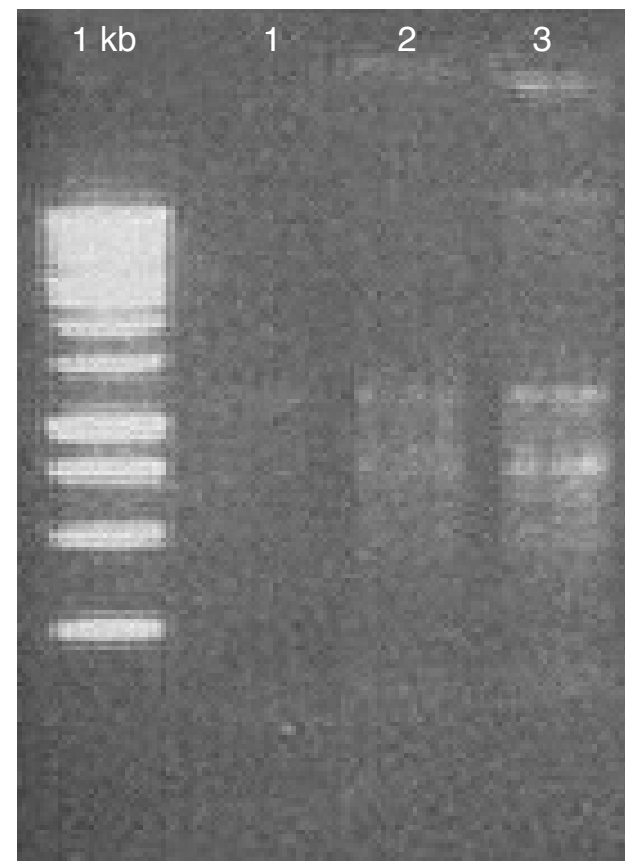

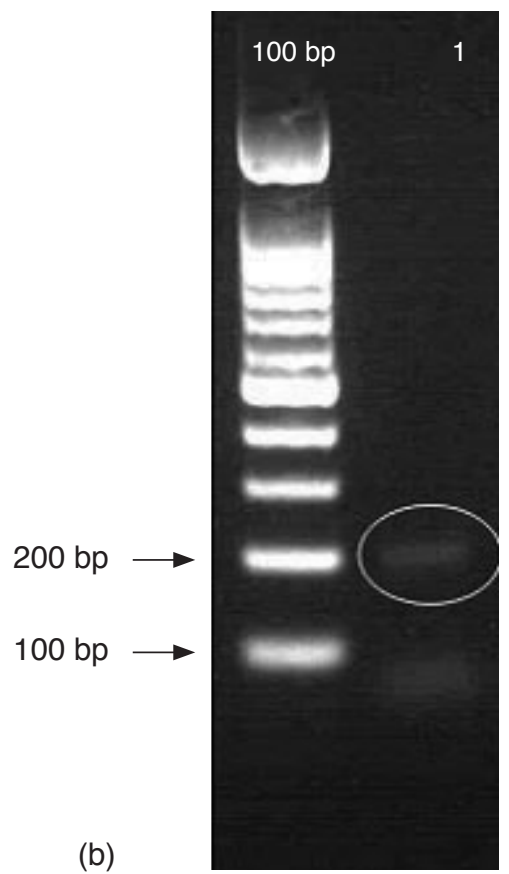

(b)

Figure 3. Gel images of A19 genomic DNA and polymerase chain reaction (PCR) product, a. Lane 2 represents genomic DNA; $b$. PCR amplification using the pairs of primers EUB 518/EUB 338. The DNA PCR product of A19 is circled.

TABLE 2. THE FIRST FIVE CLOSEST IDENTITIES OF A19 FROM NCBI GENBANK DATABASE

\begin{tabular}{|c|c|c|c|c|c|c|c|}
\hline Isolate & Accession No. & Description & Max score & Total score & Query value & E value & Identity \\
\hline \multirow[t]{5}{*}{$\begin{array}{l}\mathrm{A} 1 \mathrm{~A} 4 \\
2 \mathrm{~A} 485 \\
3.949\end{array}$} & КС928120.1 & $\begin{array}{l}\text { Streptomyces sp. ZZY-2013 } \\
\text { strain TRM46927 16S } \\
\text { ribosomal RNA gene, } \\
\text { partial sequence }\end{array}$ & 226 & 226 & $87 \%$ & $1 e-55$ & $97 \%$ \\
\hline & NR115264.1 & $\begin{array}{l}\text { Streptomyces sundarbansensis } \\
\text { strain MS1/7 16S ribosomal } \\
\text { RNA gene, partial sequence }\end{array}$ & 226 & 226 & $87 \%$ & $1 e-55$ & $97 \%$ \\
\hline & FJ475362.1 & $\begin{array}{l}\text { Uncultured streptomycete } \\
\text { clone AhedenS22 } 16 S \text { ribosomal } \\
\text { RNA gene, partial sequence }\end{array}$ & 226 & 226 & $87 \%$ & $1 e-55$ & $97 \%$ \\
\hline & AJ576404.1 & $\begin{array}{l}\text { Uncultured bacterium partial } \\
16 \mathrm{~S} \text { rRNA gene, clone PeM32 }\end{array}$ & 226 & 226 & $87 \%$ & $1 e-55$ & $97 \%$ \\
\hline & KC122238.1 & $\begin{array}{l}\text { Streptomyces sp. vh6 } 16 S \\
\text { ribosomal RNA gene, } \\
\text { partial sequence }\end{array}$ & 226 & 226 & $87 \%$ & $1 e-55$ & $97 \%$ \\
\hline
\end{tabular}

GNNNNNCNNGTCTCTCCGGCAGGTCCGTCACTTGCGCTTCTTCCTGGCT
GAAGAGGTTTACAACCCGAAGGGCCGTCATCCCTCACGCGGCGTCGCT
GCATCAGGCTTTCGCCCATTGTGCAATATTCCCCACTGCTGCCTCCCGTA
GGAGTA

Figure 4. A19 sequences used for BLAST search at NCBI GenBank database. 
G. boninense growth after seven days of incubation, while hexane extract had no inhibition to $G$. boninense. The macroscopic features of $G$. boninense mycelia growth at different concentrations of different extracts are shown in Figure 6.

\section{MIC of Streptomyces spp. A19 Crude Ethyl Acetate Extract against G. boninense}

G. boninense growth treated with different concentrations of Streptomyces spp. A19 ethyl acetate crude extracts from Day one to Day seven is shown in Figure 7. There was no visible growth of G. boninense observed at the concentration of $0.18 \mathrm{mg}$ $\mathrm{ml}^{-1}$ to $0.20 \mathrm{mg} \mathrm{ml}^{-1}$. Thus, MIC for Streptomyces spp. A19 ethyl acetate crude extract was determined at concentration of $0.18 \mathrm{mg} \mathrm{ml}^{-1}$.

\section{Anti-microbial Activity of Solid Phase Extraction} (SPE) Fractions of Streptomyces spp. A19 against G. boninense

The anti-microbial efficacy of Streptomyces spp. A19 SPE wash and elute fractions were tested



Figure 5. Percentage inhibition of G. boninense growth at different concentrations of Streptomyces spp. A19 with different solvent extracts.


Figure 6. Anti-microbial assays of different concentrations of Streptomyces spp. A19 extracts with different solvents. a. Ethyl acetate extract; b. Hexane extract; $c$. Acetone extract; d. Control. Scale bar: $2 \mathrm{~cm}$, DMSO - dimethyl sulfoxide. 




Figure 7. The growth diameter of $G$. boninense at different concentrations of Streptomyces spp. A19 ethyl acetate crude extracts.

against $G$. boninense. The lowest mean diameters of G. boninense growth was $2.43 \mathrm{~cm}$ in A19C18(E) fraction with $71.41 \%$ of growth inhibition while the highest mean diameters were $4.70 \mathrm{~cm}$ in A19SI-1(E) fraction with $44.71 \%$ of growth inhibition (Table 3).

TABLE 3. ANTI-MICROBIAL EFFICACY OF SPE FRACTIONS OF Streptomyces spp. A19 AT $0.02 \mathrm{mg} \mathrm{ml}^{-1}$ CONCENTRATION

\begin{tabular}{lcc}
\hline Samples & $\begin{array}{c}\text { Growth of G. boninense } \\
\text { (diameter in cm) }\end{array}$ & $\begin{array}{c}\text { Growth } \\
\text { inhibition (\%) }\end{array}$ \\
\hline C18 (E) & $2.43 \pm 0.15$ & 71.41 \\
SI-1 (W) & $2.90 \pm 0.00$ & 65.88 \\
C18 (W) & $4.00 \pm 0.00$ & 52.94 \\
SI-1 (E) & $4.70 \pm 0.00$ & 44.71 \\
Control DMSO & $8.50 \pm 0.00$ & No inhibition \\
Control without DMSO & $8.50 \pm 0.00$ & No inhibition \\
\hline
\end{tabular}

Note: Original size of mycelial plug - $0.80 \mathrm{~cm}$, DMSO - dimethyl sulfoxide, E- elute, $\mathrm{W}$ - wash.

* Values are mean \pm Standard deviation of three replicates.
Identification of Corresponsing Compounds of Streptomyces spp. A19 SPE Extract against G. boninense Using LC-MS

Fractions that gave good inhibitory effect to G. boninense were selected for further identification based on published results on their anti-microbial activity (Figures 8 and 9). Potential anti-microbial compound (Table 4) detected in A19SI-1(W) extract was identified as ribostamycin with $\mathrm{m} / \mathrm{z} 437.22$ $\left[\mathrm{M}+\mathrm{H}-\mathrm{H}_{2} \mathrm{O}\right]^{+}$. Meanwhile, potential anti-microbial compounds detected in A19C18(E) were benzylmalic acid with $\mathrm{m} / \mathrm{z} 242.10\left[\mathrm{M}+\mathrm{NH}_{4}\right]^{+}$, landomycin B with $\mathrm{m} / \mathrm{z} 509.19[\mathrm{M}+2 \mathrm{Na}]^{2+}$ and Salinomycin $[\mathrm{M}+\mathrm{K}]^{+}$ with $\mathrm{m} / \mathrm{z} 789.44$.

\section{DISCUSSION}

Forest soil has higher microbial population compared to disturbed soil such as plantation soil. The relatively dense growth of plants and higher accumulation of litter on the forest floor and distribution of fine roots in undisturbed forest favor

TABLE 4. POTENTIAL COMPOUNDS CONTRIBUTE TO THE ANTI-MICROBIAL ACTIVITY OF Streptomyces spp. A19 SPE EXTRACTS AGAINST G. boninense

\begin{tabular}{llllll}
\hline Sample & Compound & & $\mathbf{m} / \mathbf{z}$ & Formula & References \\
\hline SI-1 (W) & Ribostamycin & {$\left[\mathrm{M}+\mathrm{H}_{-}-\mathrm{H}_{2} \mathrm{O}\right]^{+}$} & 437.22 & $\mathrm{C}_{17} \mathrm{H}_{34} \mathrm{~N}_{4} \mathrm{O}_{10}$ & Okba et al. (2013) \\
C18 (E) & Benzylmalic acid & {$\left[\mathrm{M}+\mathrm{NH}_{4}\right]^{+}$} & 242.10 & $\mathrm{C}_{11} \mathrm{H}_{12} \mathrm{O}_{5}$ & Tanaka et al. (1984) \\
& Landomycin B & {$\left[\mathrm{M}+2 \mathrm{Na}^{2+}\right.$} & 509.19 & $\mathrm{C}_{49} \mathrm{H}_{44} \mathrm{O}_{20}$ & Mulert et al. (2003) \\
& Salinomycin & {$\left[\mathrm{M}+\mathrm{K}_{\mathrm{j}}\right]^{+}$} & 789.44 & $\mathrm{C}_{42} \mathrm{H}_{70} \mathrm{O}_{11}$ & $\begin{array}{l}\text { Lindsay and Blagburn } \\
\text { (1995) }\end{array}$ \\
\hline
\end{tabular}

Note: $\mathrm{E}$ - elute, $\mathrm{W}$ - wash. 
a.
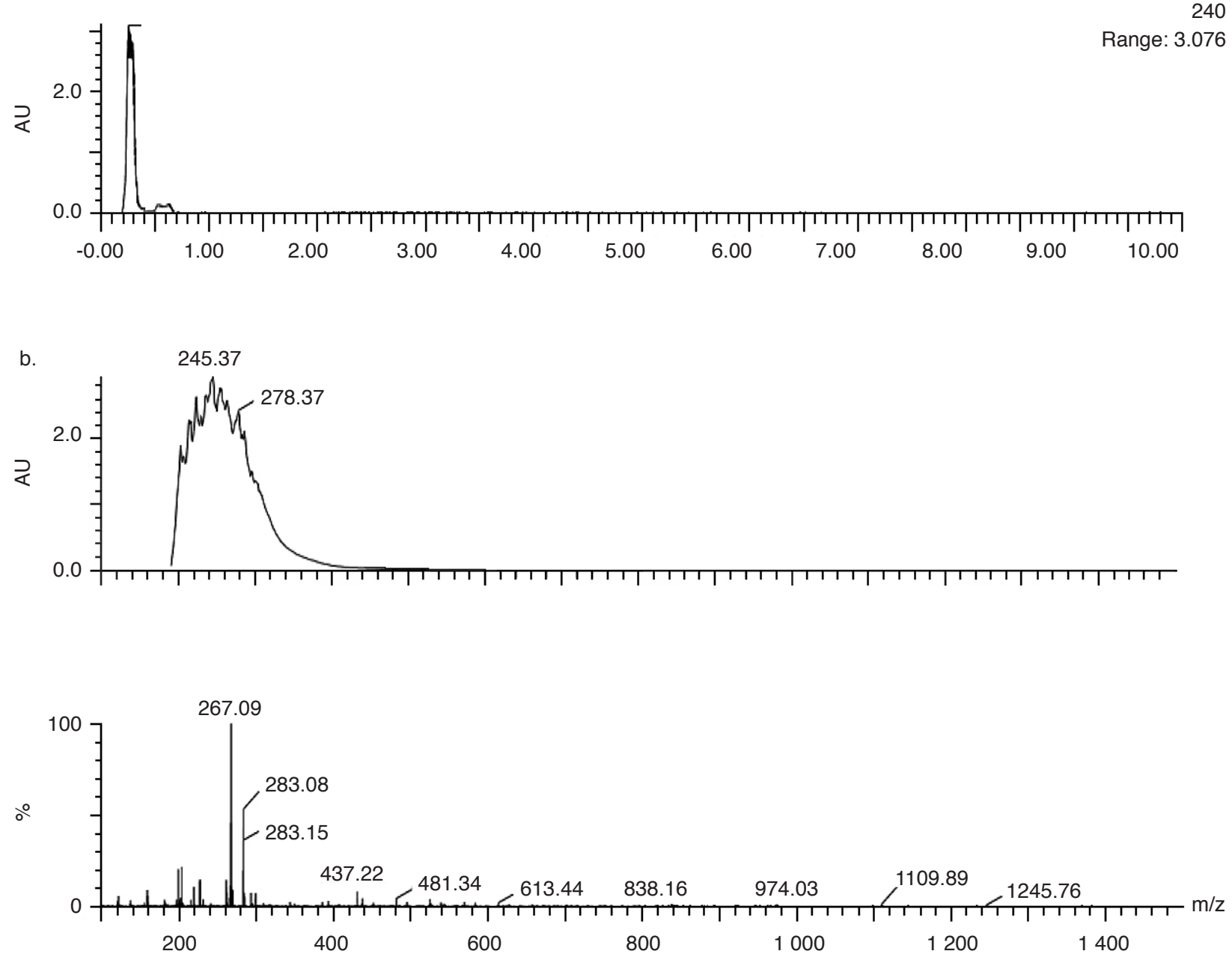

Figure 8. UV chromatogram and mass spectra of A19SI-1(W) extract obtained from liquid chromatography-mass spectrometry (LC-MS) analysis, a. Chromatogram of A19SI-1(W) extract; $b$. UV and mass spectra at $t_{R} 0.25$ min. Potential anti-microbial compound detected in the mass spectra; Ribostamycin $\left[\mathrm{M}+\mathrm{H}-\mathrm{H}_{2} \mathrm{O}\right]^{+} \mathrm{m} / \mathrm{z}$ 437.22.

the growth of microorganisms (Dkhar et al., 2012). From dual culture assays, the growth of G. boninense might be inhibited by bioactive compounds produced by Streptomyces spp. A19. SEM (Figure 2b) revealed lower density of $G$. boninense hyphal mat compared to control. Cellular changes in the hyphal morphology of G. boninense was also observed. Degradation of cell wall component to some extent resulted in hyphal abnormality. Abnormalities in fungal hyphae are due to morphological changes of impaired growth of fungal hyphal (Suryanto et al., 2012). These might be caused by secondary metabolites secreted from Streptomyces A19. The recent isolate of $S$. sundarbansensis from sediments of the Sundarbans mangrove forest in India was reported to produce 2-allyloxyphenol (Arumugam et al., 2011). Hydroxyl and allyloxy groups in 2-allyloxyphenol are responsible for many antimicrobial and antioxidant activities.
The ethyl acetate extract of Streptomyces spp. A19 showed effective results against G. boninense. This could be related to the presence of bioactive metabolites which are soluble in ethyl acetate and might be a moderately polar to polar in nature. For comparison between SPE fractions and crude extracts, SPE fractions of Streptomyces spp. A19 showed better inhibition of $G$. boninense compared to crude extract at the same concentration $(0.02 \mathrm{mg}$ $\left.\mathrm{ml}^{-1}\right)$. This is because SPE enables the concentration and purification of analytes from solution by sorption on a solid sorbent and purification of extract after extraction (Żwir-Ferenc and Biziuk, 2006). Hence, SPE process can provide samples that are better of interfering matrix components and concentrated enough for detection.

Ribostamycin is an aminoglycosideaminocyclitol antibiotic isolated from $S$. ribosidificus, originally identified in a soil sample in Japan. 

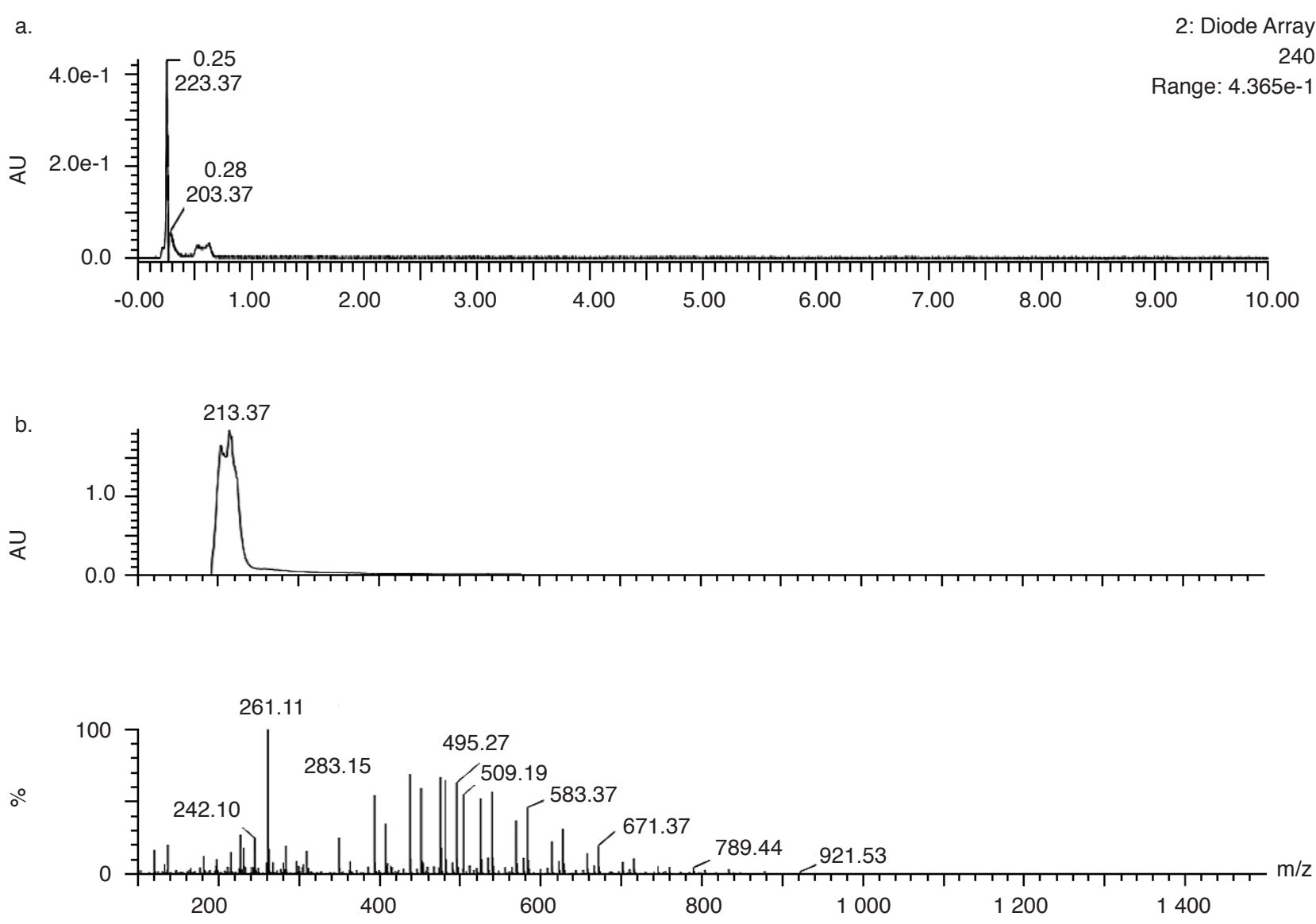

Figure 9. UV chromatogram and mass spectra of A19C18(E) extract obtained from liquid chromatography-mass spectrometry (LC-MS) analysis, a. Chromatogram of $A 19 C 18(E)$ extract; $b . U V$ and mass spectra at $t_{R} 0.25$ min. Potential anti-microbial compounds detected in the mass spectra; benzylmalic acid $\left[\mathrm{M}+\mathrm{NH}_{4}\right]^{+} \mathrm{m} / \mathrm{z} 242.10$, landomycin $\mathrm{B}[\mathrm{M}+2 \mathrm{Na}]^{2+} \mathrm{m} / \mathrm{z} 509.19$, and salinomycin $[\mathrm{M}+\mathrm{K}]^{+} \mathrm{m} / \mathrm{z} 789.44$.

Tanaka et al. (1984), reported carboxypeptidase A, (S)-a-benzylmalic acid from the culture filtrate of S. hygroscopicusas inhibitors of carboxypeptidase A. Carboxypeptidase serves as a useful introduction to the biosynthesis (translation, transport, and proteolytic or glycosyl modifications) of many vacuolar proteins (Klionsky et al., 1990). Landomycins belong to the angucycline group of natural products, the largest group of polyketide-derived natural products. S. cyanogenus is the producer of landomycin A (LaA), a polyketide-derived antibiotic with anti-tumour activity. Salinomycin (SAM) is a fermentation product of S. albus (Lindsay and Blagburn, 1995). This compound belongs to monovalent carboxylic ionophorous polyether antibiotic that interfere with the plasma membrane ion transport system especially for alkali ions with relative $\mathrm{K}+$ selectivity, and also able to interfere with mitochondrial functions.

In general, ribostamycin (aminoglycosides) are known to interfere with translation in prokaryotic ribosomes, as well as benzylmalic acid, inhibitor of carboxypeptidase which serves as a useful introduction to the biosynthesis (translation, transport, and proteolytic or glycosyl modifications) of many vacuolar proteins. Whereas, landomycin belongs to angucycline group with interesting and diverse biological activities including enzyme inhibitors and cytostatic effects. Many antibiotics such as penicillin and vancomycin inhibit the enzymes that produce and then cross-link the strands of this polymer together (Katz and Caufield, 2003). This causes the cell wall to lose strength and the fungal mycelial malformation. It is therefore suggested that these potential compounds might affect the growth of G. boninense in the present study.

\section{CONCLUSION}

Streptomyces spp. A19 is a biological control agent isolated from Crocker Range forest of Sabah and has the potential to be further studied as a biological control agent for controlling G. boninense. Potential anti-microbial compounds from Streptomyces spp. A19 such as ribostamycin, benzylmalic acid, landomycin B and salinomycin might contribute to the inhibitory effect of G. boninense. 


\section{REFERENCES}

ALEXANDER, A and CHONG, K P (2014). Combination of biological agents in suppressing colonization of Ganoderma boninense of basal stem rot. Am. Eurasian J. Sustain. Agric., 8(7): 1-7.

ARUMUGAM, M; MITRA, A; PRAMANIK, A; SAHA, M; GACHHUI, $\mathrm{R}$ and MUKHERJEE, J (2011). Streptomyces sundarbansensis sp. nov., an actinomycete that produces 2-allyloxyphenol. Int. J. Syst. Evol. Microbiol., 61: 2664-2669.

BIVI, M R; FARHANA, M S N; KHAIRULMAZMI, A and IDRIS, A S (2010). Control of Ganoderma boninense: A causal agent of basal stem bot disease in oil palm with endophyte bacteria in vitro. Int. J. Agric. Biol., 12: 833-839.

CHAUDHARY, H S; YADAV, J; SHRIVASTAVA, A R; SINGH, S; SINGH, A K and GOPALAN, N (2013). Antibacterial activity of actinomycetes isolated from different soil samples of Sheopur (A City of Central India). J. Adv. Pharm. Tech. Res., 4: 118-23.

CHONG, K P; LUM, M S; FOONG, C P; WONG, C M V L; ATONG, M and ROSSALL, S (2011). First identification of Ganoderma boninense isolated from Sabah based on PCR and sequence homology. Afr. J. Biotechnol., 10(66): 14718-14723.

CHUNG, G F (1990). Preliminary results on trunk injection of fungicides against Ganoderma basal stem rot in oil palm. Proc. of the Ganoderma Workshop. PORIM, Bangi. p. 81-97.

DKHAR, M; DKHAR, MS and TYNSONG, H (2012). Microbial activities and nutrient dynamics in sacred forest of meghalaya. Indian J. Inn. Dev., 1(3): 175-185.

GEORGE, S T; CHUNG, G F and ZAKARIA, K (1996). Updated results (1990-1995) on trunk injection of fungicides for the control of Ganoderma basal stem rot. Proc. of the PIPOC 1996 International Palm Oil Congress - Agriculture Conference (Ariffin, D et al., eds.). PORIM, Bangi. p. 508-515.

KATZ, A H and CAUFIELD, C E (2003). Structurebased design approaches to cell wall biosynthesis inhibitors. Curr. Pharm. Des., 9(11): 857-66.

KLIONSKY, D J; HERMAN, P K and EMR, S D (1990). The fungal vacuole: composition, function, and biogenesis. Microbiol. Rev., 54(3): 266-292.

LAKSHMI, P and SELVI, K (2013). Anticancer potentials of secondary metabolites from endophytes of Barringtonia acutangula and its molecular characterization. Int. J. Curr. Microbiol. Appl. Sci., 2: 44-45.
LATIFAH, Z; HARIKRISHNA, K; TAN, S G; ABDULLAH, F and HO, Y W (2002). Restriction analysis and sequencing of the ITS regions and $5.8 \mathrm{~S}$ gene of rDNA of Ganoderma isolates from infected oil palm and coconut stumps in Malaysia. Ann. Appl. Biol., 141: 133-142.

LINDSAY, D S and BLAGBURN, B L (1995). Antiprotozoan drugs. Veterinary Pharmacology and Therapeutics (by Adams, H R ed.). Iowa State University Press, Amsterdam. p. 969-983.

MAIZATUL, S M and IDRIS, A S (2009). Nursery evaluation of Agrobacterium radiobacter, Burkholderia cepacia and Pseudomonas syringae to control Ganoderma boninense infection in oil palm. Proc. of the PIPOC 2009 International Palm Oil Congress - Agriculture, Biotechnology and Sustainability Conference. p. 1301-1312.

MPOB (2017). Overview of the Malaysia oil palm industry 2016. http:// bepi.mpob.gov.my/images/ overview/Overview_of_Industry_2016.pdf

MULERT, V; LUZHETSKYY, A; HOFMANN, C; MAYER, CA and BECHTHOLD, A(2004). Expression of the landomycin biosynthetic gene cluster in a PKS mutant of Streptomyces fradiae is dependent on the coexpression of a putative transcriptional activator gene. FEMS Microbiol. Lett., 230(1): 91-97.

OKBA, N M; ANWAR, K M; EL-BANNA, T S S and EL-AZIZ, A A A (2013). Isolation, heterologous expression and gene duplication of certain ribostamycin biosynthetic genes from Streptomyces ribosidificus NRRL B-11466. Arch. Clin. Microbiol., 4(6): $1-10$

SHARIFFAH-MUZAIMAH, S A; IDRIS, A S; DZOLKHIFLI, O; KAMARUZZAMAN, S; CHEONG, C H and SATOSHI, N (2011). Isolation of potential actinomycetes from oil palm (Elaeis guineensis) plantations as biological control of ganoderma disease. Proc. of the Third MPOB-IOPRI International Workshop Seminar: Integrated Oil Palm Pests and Disease Management. p. 192-196.

SOEPENA, H; PURBA, R Y and PAWIROSUKARTO, S (2000). A control strategy for basal stem rot (Ganoderma) on oil palm. Ganoderma Diseases of Perennial Crops (Flood, J; Bridge, P D and Holderness, M eds.). CABI Publishing, Wallingford, UK. p. 83-88.

SURYANTO, D; WIBOWO, R H; SIREGAR, E B M and MUNIR, E (2012). A possibility of chitinolytic bacteria utilization to control basal stems disease caused by Ganoderma boninense in oil palm seedling. Afr. J. Microbiol. Res., 6(9): 2053-2059. 
SUSANTO, A; SUDHARTO, P S and PURBA, R $Y$ (2005). Enhancing biological control of basal stem rot disease (Ganoderma boninense) in oil palm plantations. Mycopathologia, 159(1): 153-157.

TAN, C J; HOW, K C; LOH-MIA, P P; ISMET, A; GETHA, K; SEKI, T and VIKINESWARY, S (2002). Bioactivity of selected actinomycetes against Ganoderma boninense. Asia Pac. J. Mol. Biol. Biotechnol., 10(2): 119-125.
TANAKA, $\mathrm{T}$; SUDA, $\mathrm{H}$; NAGANAWA, $\mathrm{H}$; HAMADA, M; TAKEUCHI, T; AOYAGI, T and UMEZAWA, H (1984). Production of (S)-alphabenzylmalic acid, inhibitor of carboxypeptidase A by actinomycetes. J. Antibiot., 37: 682-684.

ŻWIR-FERENC, A and BIZIUK, M (2006). Solid phase extraction technique - Trends, opportunities and applications. Pol. J. Environ. Stud., 15(5): 677-690. 